\title{
Contributors
}

\section{Jonathan Fulton}

is assistant professor of political science at Zayed University, in Abu Dhabi, United Arab Emirates. His research focuses on China's relations with the Middle East. He is currently working on a book to be published with Routledge titled China's Relations with the Arab Gulf Monarchies.

\section{Jane Hunter}

is professor of history at Lewis \& Clark College, and author of Gospel of Gentility: American Women Missionaries in Turn-of-the-Century China, recently translated into Chinese 优雅的福音 (Youya de fuyin). She was Fulbright Distinguished Chair in World History, Sichuan University (2012-13), and is currently working on the commitments of Isabel Brown Crook, Canadian missionary daughter, Beijing resident, and member of the Chinese revolutionary generation.

\section{Noriko K. Ishii}

is a professor in U.s. history, transnational women's history and American Studies at Sophia University in Tokyo, Japan. Her major publication is American Women Missionaries at Kobe College: New Dimensions in Gender (New York and London: Routledge, 2004).

\section{Amanda L. Izzo}

is an Assistant Professor of Women's and Gender Studies at Saint Louis University. Rutgers University Press will publish her book titled Liberal Christianity and Women's Global Activism: The YWCA of the USA and the Maryknoll Sisters in January 2018.

\section{Connie Shemo}

is an associate professor of history at Plattsburgh State University. She is the author of The Chinese Medical Ministries of Kang Cheng and Shi Meiyu: On a Cross-Cultural Frontier of Gender, Race, and Nation (Rowman and Littlefield, 2011) and of essays published in the Journal of Women's History, the Chinese Historical Review, and History Compass, among others. Shemo also is the co-editor of Competing Kingdoms: Women, Mission, and Nation in an American Protestant 
Empire (Duke University Press, 2010). Her current project is a manuscript in progress entitled "An Honorable Profession for Women": American Medical Missionary Medical Education for Chinese Women in China, 1879-1949.

\section{Mathew T. Brundage}

Mathew Brundage recently received a PhD in History from Kent State University. His dissertation, "Where We Would Extend the Moral Power of Our Civilization": American Cultural and Political Foreign Relations with China, 1843-1856,' analyzes the rhetoric that Americans used to justify calls for the United States to increase its presence and influence in East Asia during the period of the Opium Wars. 